\title{
Utricularia vulgaris L. AND Salvinia natans (L.) All. HEAVY METAL (Fe, Mn, Cu, Zn AND Pb) BIOACCUMULATION SPECIFICITY IN THE AREA OF BARDAČA FISHPOND
}

\author{
TANJA MAKSIMOVIĆ ${ }^{1}$, SRĐAN RONČEVIĆ ${ }^{2}$, BILJANA KUKAVICA ${ }^{3 *}$
}

${ }^{1}$ Department of Biology, Faculty of Natural Sciences and Mathematics, University of Banja Luka, Mladena Stojanovića 2, 78000 Banja Luka, Republic of Srpska, Bosnia and Herzegovina; e-mail: tanja.maksimovic@pmf.unibl.org

${ }^{2}$ Department of Chemistry, Biochemistry and Environmental Protection, Faculty of Sciences, University of Novi Sad, Trg Dositeja Obradovića 2, 21000 Novi Sad, Serbia; e-mail: srdjan.roncevic@dh.uns.ac.rs

${ }^{3}$ Department of Biology, Faculty of Natural Sciences and Mathematics, University of Banja Luka, Mladena Stojanovića 2, 78000 Banja Luka, Republic of Srpska, Bosnia and Herzegovina; e-mail: biljana.kukavica@pmf.unibl.org

*Author for correspondence

\begin{abstract}
Maksimović T., Rončević S., Kukavica B.: Utricularia vulgaris L. and Salvinia natans (L.) All. heavy metal ( $\mathrm{Fe}, \mathrm{Mn}, \mathrm{Cu}, \mathrm{Zn}$ and $\mathrm{Pb}$ ) bioaccumulation specificity in the area of Bardača fishpond. Ekológia (Bratislava), Vol. 38, No. 3, p. 201-213, 2019.

Paper deals with seasonal changes in heavy metal bioaccumulation ( $\mathrm{Fe}, \mathrm{Mn}, \mathrm{Cu}, \mathrm{Zn}$ and $\mathrm{Pb}$ ) in Utricularia vulgaris L. and Salvinia natans (L.) All. of two localities (Necik and Sinjak - active fishpond basins) in the area of Bardača fishpond. According to our results, the better accumulator of Fe $(3035 \mathrm{mg} / \mathrm{kg})$ and $\mathrm{Zn}$ was S. natans $(163.55 \mathrm{mg} / \mathrm{kg})$, whereas Utricularia vulgaris better accumulates $\mathrm{Mn}(620 \mathrm{mg} / \mathrm{kg})$ and $\mathrm{Cu}(10.18 \mathrm{mg} / \mathrm{kg})$. Amounts of $\mathrm{Pb}$ in both investigated macrophyte were below the detection level $(<0.51 \mathrm{mg} / \mathrm{kg})$. The values of the bioaccumulation factor (BAC) of the tested metals were $>1$ or $\sim 1$ for both species, and the BAC values decreased in the following order in both investigated species: $\mathrm{Fe}>\mathrm{Mn}>\mathrm{Cu}>\mathrm{Zn}$. The results obtained indicated that tested macrophyte show very good characteristics as bioaccumulators and, thanks to this fact, they could be used in phytoremediation technique successfully in water-polluted ecosystem.
\end{abstract}

Key words: heavy metals, bioaccumulation, Utricularia vulgaris L., Salvinia natans (L.).

\section{Introduction}

Heavy metals are natural components of Earth's crust, but in many ecosystems, concentration of certain heavy metals reached toxic levels because of consequences of anthropogenic activities. In the recent years, pollution of environment with heavy metals has become a great global problem of modern society with characteristic cumulative effect (Prasad, 2003; Ghosh, Singh, 2005; Prasad et al., 2006; Liu et al., 2007; Rai, 2009; Nouri, Haddioui, 2016). Exposure of plants to toxic levels of heavy metals starts a wide spectrum of physiological and metabolic changes (Prasad, 2003; Prasad et al., 2006), which include the following: decrease in plant's growth, changes in cell metabolism, damage of cell membranes, inhibition of mem- 
brane proteins, changes mineral nutrition and inhibition of photosynthesis, which leads to senescence and, at the end, to plants death (Prasad, 2003; Prasad et al., 2006). Aquatic plants have a good ability to tolerate increased levels of heavy metals and accumulate them up to unusually high concentrations, causing accumulative effect without significant consequences to metabolic processes (Liu et al., 2007; Rai, 2009; Babović et al., 2010; Pant, Tripathi, 2014). Plants growing in polluted environment are very often under stress because of bioaccumulation through direct uptake by root, stem or sprouts (Prasad et al., 2006; Liu et al., 2007; Borišev et al., 2008; Rai, 2009; Babović et al., 2010).

Current technologies available for mitigation of pollution are very expensive, and in most of cases, they represent a cost for industry (Rai, 2009). Hence, lately, aquatic macrophytes are used as bioindicators of water quality and phytosanitors of water pools more often. There is a constant intention to incorporate waste water purification methods by these plants into directives. Different studies (Liu et al., 2007; Borišev et al., 2008; Rai, 2009; Babović et al., 2010) showed that aquatic macrophytes concentrate certain metals up to different degree and, hence, critical levels could vary among species.

Numerous studies of aquatic plants were performed in laboratory conditions, whereas small number of researches on potential of heavy metals bioaccumulation was made in the field environment. Owing to this, the aim of our study was to examine the ability of aquatic plants to accumulate heavy metals in their natural environment and the possibility of their use as bioindicators. Macrophytes can accumulate a considerable amount of heavy metals (10-10 $0^{6}$ times higher than their concentration in aquatic environments) in their tissue without disturbing their normal metabolism (Prasad, 2006). Plants chosen for investigation were different in position of sprout in air or water environment, as well as in relation of connection to the ground or free floating (emerged, submerged-not-rooted and floating-not-rooted) and per system of heavy metals bioaccumulation. Utricularia vulgaris (submerged-not-rooted) because of a thin cuticle absorbs heavy metals through the entire surface of the leaf from the water (Prasad, 2006), whereas Salvinia natans (floating-not-rooted) absorbs pollutants from the water and also from the air (Prasad, 2006).

\section{Material and methods}

\section{Study area}

Swamp-marsh ecosystem complex Bardača is located at the far North-East of Lijevče polje (Lijevče field in English), bordering the Sava river at North, Brzaja and Vrbas rivers at East, Matura at West, whereas perimeter canal OsornaBorna-Ljevčanica (O-B-LJ) is located in immediate vicinity at South (Fig. 1) (Šarić et al., 2004).

On 02 March 2007, Bardača was declared as Ramsar area (number 1658), which confirmed its international importance as the 'Important Bird Area'. However, after gaining Ramsar area status, under the strong anthropogenic influence, there was a significant devastation of this sensitive ecosystem. Consequently, constant monitoring and assessment of the heavy metal load in this endangered area is one of the measures of revitalisation. Previous research (Maksimović et al., 2007; Maksimović, Ilić, 2008; Maksimović et al., 2016) and our results related to the content of heavy metals in aquatic macrophytes will determine the reliability of their use for water quality monitoring as well as the role of macrophyte vegetation in the remediation of pollutants, especially during the period of intensive fish breeding.

Plants samples $(1 \mathrm{~kg}$ ) were collected in shallow parts of fishponds. From each site, the collection and analysis of whole plants of $S$. natans and Utricularia vulgaris during the vegetation season were carried out at all stages of their 


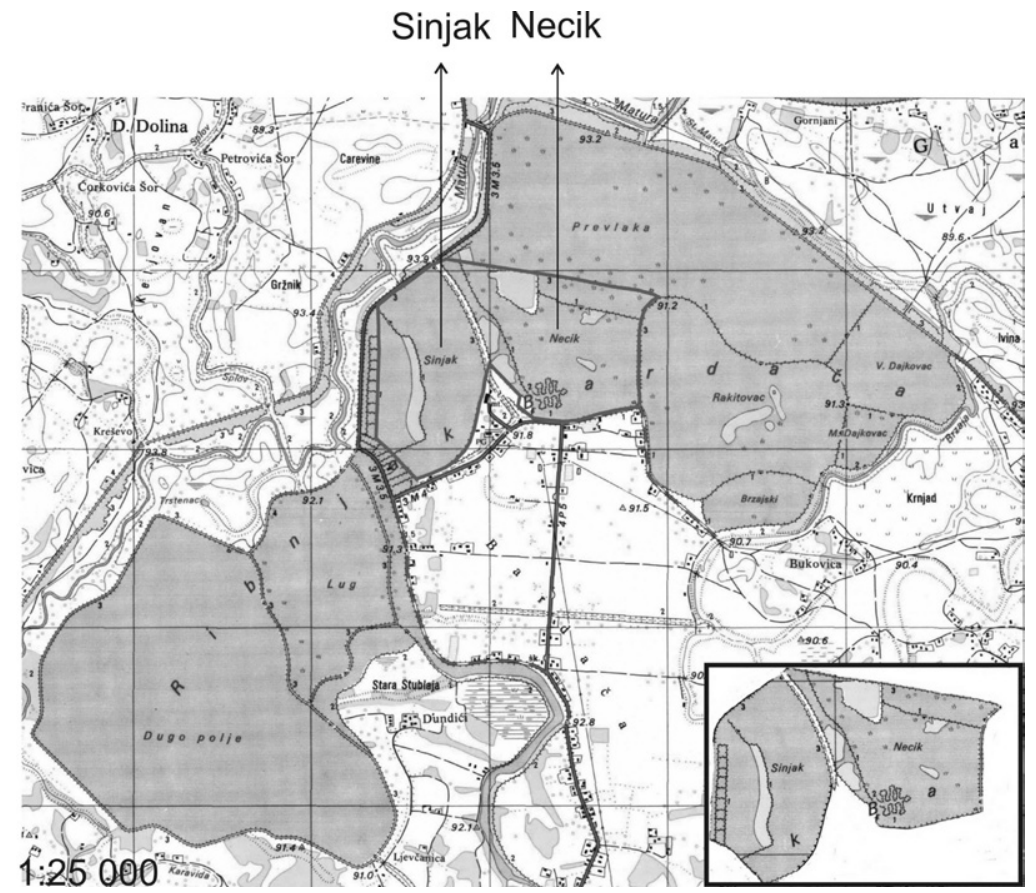

Fig. 1. Map of Bardača fishpond (a detail from topographic map 1:25,000), Nova Gradiška (Razboj-Ljevčanski) 4-4, Vojnogeografski institut, 1977 (Military Geographic Institute).

growth and development (May to September). At the same places, sediment samples were taken from a depth of 0-20 cm. Sediment was dried first at room temperature and then at $105^{\circ} \mathrm{C}$, milled to a powder and sieved through a fine sieve $(\leq 500 \mu \mathrm{m})$. Sediment samples were prepared for further analyses by standard methods (APHA, 1995).

\section{Sample analysis}

In the laboratory, plant material was sorted, rinsed in tap and distilled water, dried in dryer at $105{ }^{\circ} \mathrm{C}$ and was prepared for further chemical analysis applied for water and water plants (APHA, 1995). Concentrations of microelements (heavy metals) were defined by atomic absorption spectrophotometry (AAS) directly from basic liquid. Samples were recorded on atomic absorption spectrometer Analyst 700, produced by Perkin Elmer, USA, using flame technique, standard method EPA 7000B.

\section{Statistical analysis}

The results were statistically processed using SPSS program (Statistical Package for the Social Sciences) 13.0 POZA 69. All the analyses were performed in three independent repetitions, and the analysed parameters were processed using variance method (ANOVA) factorial experiment. On the basis of the results obtained for the metal content in this article, water categorisation was made by the Decree on Water Classification and Categorization of Watercourses, Sl. glasnik Republike Srpske (2001) and classification of sediments according to the Netherlands (VROM, 2000) and Canadian recommendations (Canadian Council of Ministers of the Environment, 1999). Each analysis was repeated three times. 
The values of BCF and BAC were used to evaluate potential plant species in phytoremediation techniques (Rahmani, 1999; Li et al., 2007). The ability of plants to accumulate heavy metals from water is estimated using the bioconcentration factor (BCF). Bioaccumulation coefficient (BAC) calculated as the ratio of heavy metal content in the above ground to the content of heavy metals in the sediment (Li et al., 2007).

$$
B A C=\frac{[\text { Metal }]_{\text {plant above-ground part }}}{[\text { Metal }]_{\text {sediment }}} .
$$

The BCF value is calculated as the ratio of the concentration of heavy metals in the tissue of plants relative to its content in water (Rahmani, Sternberg, 1999). High BCF values involve a higher ability of the plant to bioaccumulate a particular heavy metal.

$$
B C F=\frac{[\text { Metal }]_{\text {part of plant }}}{[\text { Metal }]_{\text {wather }}} .
$$

\section{Results and discussion}

\section{Heavy metal concentration in water}

The results of Maksimović and coworkers (Maksimović et al., 2007, 2016) showed increased concentrations of $\mathrm{Pb}$ and $\mathrm{Zn}$ in fishponds, Necik and Sinjak. On the basis of the concentrations of $\mathrm{Pb}$ and $\mathrm{Zn}$ and according to the Regulation on Classification of Water and Categorization of Watercourses (2001), investigated fishponds belonged to the class III/IV of water quality. On the other hand, according to the concentrations of $\mathrm{Fe}, \mathrm{Mn}$ and $\mathrm{Cu}$, the investigated fishponds belonged to class III/IV (Fig. 2). The authors emphasised that fishponds are waste water recipes: agricultural activities near the pool can cause pollution in an extent that is higher than the pools self-purification, which leads to an increase in the content of heavy metals.
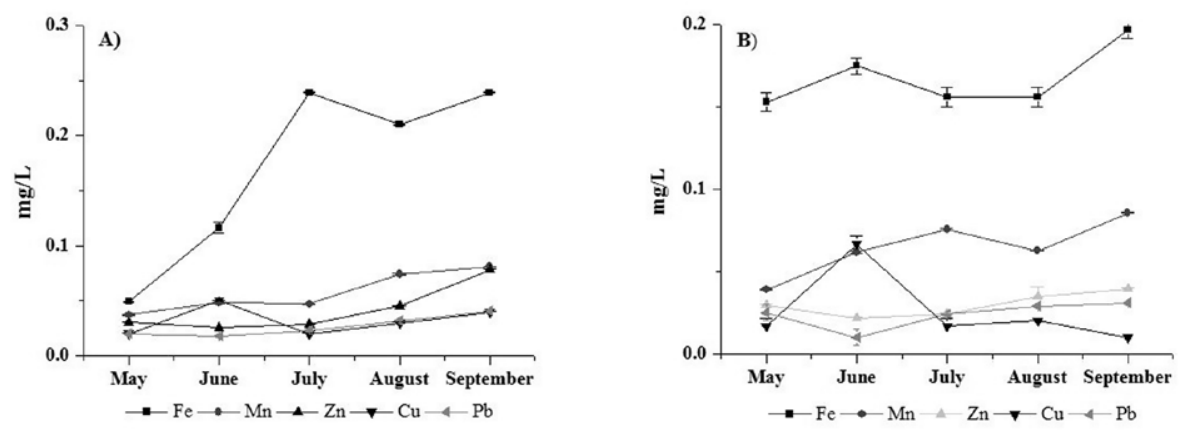

Fig. 2. Average values of heavy metal content in water at research sites (mg/L) for locality Necik (left) and Sinjak (right) during the period from May to September. 


\section{Heavy metal concentration in sediments}

We measured the content of heavy metals ( $\mathrm{Fe}, \mathrm{Mn}, \mathrm{Zn}$ and $\mathrm{Pb}$ ) in sediments of fishponds, Sinjak and Necik, as well as their content in tissues of U. vulgaris and Salvinia natans. Fe content in the sediments on both the investigated fishponds was significantly higher compared to other metals (Table 1).

$\mathrm{T}$ a b l e 1 . Heavy metal contents ( $\mathrm{Fe}, \mathrm{Mn}, \mathrm{Zn}, \mathrm{Cu}$ and $\mathrm{Pb})$ in sediment on Necik and Sinjak locality (mg/kg). Values are expressed as mean \pm SD $(n=3)$. The different letters in each row show a statistically significant difference $(\mathrm{p}<$ $0.05)$ for one heavy metal per month.

\begin{tabular}{|c|c|c|c|c|c|c|}
\hline \multirow{4}{*}{} & \multirow{2}{*}{ Heavy metal } & \multicolumn{5}{|c|}{ Period (month) } \\
\cline { 2 - 7 } & & May & June & July & August & September \\
\hline \multirow{3}{*}{ Necik } & $F e$ & $618.33^{\mathrm{a}}$ & $615.82^{\mathrm{b}}$ & $616.66^{\mathrm{b}}$ & $619.16^{\mathrm{a}}$ & $619.16^{\mathrm{a}}$ \\
\cline { 2 - 7 } & $M n$ & $206.66^{\mathrm{d}}$ & $257.50^{\mathrm{b}}$ & $226.66^{\mathrm{c}}$ & $189.99^{\mathrm{e}}$ & $224.99^{\mathrm{c}}$ \\
\cline { 2 - 7 } & $Z n$ & $66.74^{\mathrm{d}}$ & $63.33^{\mathrm{e}}$ & $69.74^{\mathrm{b}}$ & $71.66^{\mathrm{a}}$ & $71.00^{\mathrm{a}}$ \\
\cline { 2 - 7 } & $C u$ & $6.08^{\mathrm{d}}$ & $7.16^{\mathrm{c}}$ & $17.72^{\mathrm{a}}$ & $10.50^{\mathrm{b}}$ & $6.91^{\mathrm{d}}$ \\
\hline \multirow{5}{*}{ Sinjak } & $F e$ & $620.00^{\mathrm{a}}$ & $618.33^{\mathrm{b}}$ & $617.49^{\mathrm{c}}$ & $618.33^{\mathrm{b}}$ & $618.33^{\mathrm{b}}$ \\
\cline { 2 - 7 } & $M n$ & $355.83^{\mathrm{a}}$ & $345.83^{\mathrm{a}}$ & $250.83^{\mathrm{c}}$ & $204.49^{\mathrm{d}}$ & $292.49^{\mathrm{b}}$ \\
\cline { 2 - 7 } & $Z n$ & $67.25^{\mathrm{a}}$ & $60.00^{\mathrm{b}}$ & $55.16^{\mathrm{c}}$ & $51.66^{\mathrm{d}}$ & $60.08^{\mathrm{b}}$ \\
\cline { 2 - 7 } & $C u$ & $9.99^{\mathrm{a}}$ & $6.99^{\mathrm{b}}$ & $2.83^{\mathrm{f}}$ & $5.83^{\mathrm{d}}$ & $5.16^{\mathrm{e}}$ \\
\hline
\end{tabular}

Concentration of Fe was in the range $616.66-620 \mathrm{mg} / \mathrm{kg}$, and in the fishpond Sinjak, higher Fe content was measured in comparison with the pond Necik. The values that we measured for Fe in the sediment of Sinjak and Necik were lower compared to that of Srebrno jezero (9.060 mg/kg) (Yurkova, Kochev, 1996), Begečka jama (1.2374 mg/kg) and Koviljski rit $(16.154 \mathrm{mg} / \mathrm{kg}$ ) (Štrbac et al., 2014). Mn content in the sediment varied more during the season (Table 1) and was two to three times lower than Fe contents. However, the measured concentrations of $\mathrm{Mn}$ was five times higher in relation to the previously obtained results on the same localities (Maksimović, Ilić, 2008) and also higher in comparison with other studies of similar localities (Yurkova, Kochev, 1996; Stanković et al., 2000; Pajević et al., 2002) where authors stated that Mn concentration varied depending on the adoption ability of aquatic macrophytes and chemical conditions of sediment. Zinc content in sediment of Necik during the research period was in the range $63-71 \mathrm{mg} / \mathrm{kg}$, and that in Sinjak was $51-67 \mathrm{mg} / \mathrm{kg}$, wherein the highest $\mathrm{Zn}$ concentration was measured in July in Necik sediment. Compared to localities Obedska Bara, Ludoš, Carska Bara (Prica et al., 2005), Tisa River (Štrbac et al., 2014) and Velenjsko jezero (Slovenia) (Grudnik, 2010), the detected values for Zn on the research localities were significantly lower. As was shown in previous research, the higher zinc concentrations in river sediments is in soluble form, associated with Fe and Mn oxide, carbonate and organic matter, whereas $30 \%$ of $\mathrm{Zn}$ is not dissolved (Tyler, Olsson, 2001), which probably resulted in lower content of $\mathrm{Zn}$ in the sediment compared to that of Fe and $\mathrm{Mn}$. It is known that in acidic environment and in oxidising conditions, contents of soluble form of zinc are increased (Tyler, Olsson, 2001), so it could be assumed that changes in $\mathrm{pH}$ and oxygen contents during season affected the availability of $\mathrm{Zn}$ in sediment of researched basins. 
Copper contents in the sediment of Sinjak and Necik (Table 1) were significantly lower comparing to those in other researched elements. So, Cu contents in Necik locality during the research period was in the range $6.08-17.72 \mathrm{mg} / \mathrm{kg}$, and that in Sinjak locality was in the range 2.83-9.99 $\mathrm{mg} / \mathrm{kg}$, whereas in Necik locality, 34\% higher contents of $\mathrm{Cu}$ was measured. Compared to localities Obedska Bara, Ludoš, Carska Bara (Prica et al., 2005), Palićko jezero (Raičević et al., 2011), Tisa River (Štrbac et al., 2014) and Velenjsko jezero (Grudnik, 2010), where Cu values exceeded the allowed limits, significantly lower values were detected in the basins of Bardača fishpond. Our data indicate that the level of $\mathrm{Cu}$ in the area of the fishpond Bardača not reached a critical level and that should not have a negative impact on the plant growth and development. Considering the fact that it is a mildly alkali soil, and because availability of copper decreases when $\mathrm{pH}$ values are more than 7 (Šarić et al., 2004), this could explain lower values of $\mathrm{Cu}$ in this area. Concentrations of available $\mathrm{Pb}$ in sediment are most often very low, because of its strong connection to organic substance, Fe-Mn oxides, clay and deposition in the form of carbonates, hydroxides and phosphates (Prasad et al., 2006; Tyler, Olsson, 2001). Lead values in the sediment of Sinjak and Necik were under the detected limit $(<0.51 \mathrm{mg} / \mathrm{kg})$ in contrast to previous studies in this area when the lead concentrations were in the range $27.62-32.26 \mathrm{mg} / \mathrm{kg}$ (Maksimović et al., 2007). If we compare concentrations of heavy metals (Table 1) in the sediment of the researched fishponds with Netherlands (VROM; 2000) and Canadian recommendations (1999), it can be concluded that the ponds were unpolluted by the investigated metals.

\section{Heavy metal concentrations in plant organs}

Depending on species, seasonal cycle of aquatic macrophytes is characterised by slower or faster growth in spring, peak of growth at the end of summer and smaller or bigger fall in autumn, so it is considered that macrophytes could affect seasonal storage and metal circulation in aquatic environment (Prasad et al., 2006). Degree of heavy metal accumulation in tissues of investigated macrophyte was not consistent with their contents in sediment. Therefore, the content of Fe and $\mathrm{Mn}$ in the tissue of $S$. natans and Utricularia vulgaris was significantly higher than that in the sediment.

In contrast, immersed, floating and submerged species accumulate metals in leaves and thus significantly contribute to the extraction of heavy metals from water basins (Prasad et al., 2006). The correction is fine The content of $\mathrm{Zn}$ in the tissue of the investigated macrophytes did not significantly differ from the content in the sediment. In contrary, the measured copper concentrations were lower in the tissue compared to those of $\mathrm{Fe}, \mathrm{Mn}$ and $\mathrm{Zn}$ and did not correlate with the concentrations in sediments, indicating a lower translocation of $\mathrm{Cu}$ in plant tissues.

\section{Accumulation of iron}

The results obtained indicate different Fe concentrations in the tissue of examined plant species (Table 2).

Fe is one of the essential elements; however, high concentrations of Fe may be very harmful for the plants. Fe is a redox active metal that, through the Fenton reac- 
T a b l e 2. Fe contents (mg/kg) in tissues of Salvinia natans and Utricularia vulgaris on two researched localities. The different letters in each row show a statistically significant difference $(\mathrm{p}<0.05)$ for one heavy metal per month.

\begin{tabular}{|c|l|c|c|c|c|c|}
\hline \multirow{2}{*}{ Plant species } & \multicolumn{5}{c|}{ Period (month) } \\
\cline { 3 - 7 } \multicolumn{2}{|c|}{ Necik } & May & June & July & August & September \\
\hline \multirow{2}{*}{ Sinjak } & Utvinia natans & $3035^{\mathrm{a}}$ & $1539^{\mathrm{b}}$ & $1190^{\mathrm{c}}$ & $866^{\mathrm{d}}$ & $454^{\mathrm{e}}$ \\
\cline { 2 - 7 } & Stricularia vulgaris & $1184^{\mathrm{a}}$ & $938^{\mathrm{b}}$ & $874^{\mathrm{d}}$ & $893^{\mathrm{c}}$ & $741^{\mathrm{e}}$ \\
\cline { 2 - 7 } & Utricularia natans & - & $1646^{\mathrm{a}}$ & $720^{\mathrm{d}}$ & $875^{\mathrm{b}}$ & $758.26^{\mathrm{c}}$ \\
\hline
\end{tabular}

tion, leads to the formation of hydroxyl radicals, which is highly reactive and can cause damage and death of plant cells (Dhir, Srivastava, 2013).

In the tissue of Salvinia natans, Fe contents varied from 453.74 to $3035.20 \mathrm{mg} / \mathrm{kg}$. During season, higher values were measured in the beginning of vegetation period (May) and significantly lower $(80 \%)$ by the end of research period (September). Fe content in the tissue of $S$. natans was in accordance with the research of other authors for Ribnjak Ečka (198-5979 mg/kg; Babović et al., 2010) and Jegrička River (2.527 mg/kg; Borišev et al., 2008). Fe concentrations in tissue of $S$. natans were twofold higher at Necik locality compared to Sinjak. Grisey et al. (2012) showed in their studies that seasonal changes in heavy metals contents depend on dynamics in plant growth and ability of metal translocation from roots to leaves, which could also be connected to the results obtained in this study.

The highest $\mathrm{Fe}$ value in the tissue of Utricularia vulgaris $(1.184 \mathrm{mg} / \mathrm{kg}$ ) was measured in May on Necik locality, whereas by the end of research period, the values were up to $60 \%$ lower. Stanković et al. (2000) showed that increase in Fe values in tissue of submerged species Myriophyllum spicatum and Ceratophyllum demersum $(1.157-2.075 \mathrm{mg} / \mathrm{kg}$ ) in Vrbas-Bezdan and Banatska Palanka-Novi Bečej canals results from surrounding agricultural surfaces as well as emission of metals from sediments, which most probably is one of the reasons for increased Fe concentration in this area. Submerged aquatic macrophytes (Utricularia vulgaris) accumulate significantly higher heavy metal concentrations, which was also supported by other researches (Borišev et al., 2008; Babović et al., 2010). During season, different distribution of Fe accumulation was detected; higher concentration was recorded at the beginning of vegetation period at Necik locality, whereas the opposite observation was observed at Sinjak locality. Also, during the season(May- September), Fe contents varied in tissue of Salvinia natans and Utricularia vulgaris: the highest level was measured in growing period (MayJune), followed by a significant reduction at the end of vegetation period. Similar results have been demonstrated by Grudnik and co-workers (Grudnik, 2010) in their research of some submerged and floating plants.

\section{Accumulation of manganese}

Different adoption of Mn (Table 3) amongst submerged and floating species was also pointed out by other researchers (Yurkova, Kochev, 1996; Pajević et al., 2002; Borišev et al., 2008; Branković et al., 2009; Babović et al., 2010). 
$\mathrm{T} \mathrm{a} \mathrm{b} \mathrm{l} \mathrm{e} \mathrm{3.} \mathrm{Mn} \mathrm{contents}(\mathrm{mg} / \mathrm{kg})$ in tissues of Salvinia natans and Utricularia vulgaris at researched localities. The different letters in each row show a statistically significant difference $(\mathrm{p}<0.05)$ for one heavy metal per month.

\begin{tabular}{|c|l|c|c|c|c|c|}
\hline \multicolumn{2}{|c|}{ Plant species } & \multicolumn{5}{c|}{ Period (month) } \\
\cline { 2 - 7 } \multicolumn{2}{|c|}{} & May & June & July & August & September \\
\hline \multirow{2}{*}{ Necik } & Salvinia natans & $350^{\mathrm{d}}$ & $399^{\mathrm{c}}$ & $579^{\mathrm{a}}$ & $481^{\mathrm{b}}$ & $266^{\mathrm{e}}$ \\
\cline { 2 - 7 } & Utricularia vulgaris & $620^{\mathrm{a}}$ & $440^{\mathrm{e}}$ & $495^{\mathrm{b}}$ & $497^{\mathrm{c}}$ & $453^{\mathrm{d}}$ \\
\hline \multirow{2}{*}{ Sinjak } & Salvinia natans & - & $374^{\mathrm{c}}$ & $446^{\mathrm{b}}$ & $479^{\mathrm{a}}$ & $325^{\mathrm{d}}$ \\
\cline { 2 - 7 } & Utricularia vulgaris & $382^{\mathrm{e}}$ & $410^{\mathrm{d}}$ & $520^{\mathrm{a}}$ & $424^{\mathrm{c}}$ & $472^{\mathrm{b}}$ \\
\hline
\end{tabular}

$\mathrm{T}$ a b 1 e 4 . Zn contents $(\mathrm{mg} / \mathrm{kg})$ in tissues of Salvinia natans and Utricularia vulgaris at researched localities. The different letters in each row show a statistically significant difference $(\mathrm{p}<0.05)$ for one heavy metal per month.

\begin{tabular}{|l|l|c|c|c|c|c|}
\hline \multirow{2}{*}{ Plant species } & \multicolumn{5}{c|}{ Period (month) } \\
\cline { 3 - 7 } & & May & June & July & August & September \\
\hline \multirow{2}{*}{ Necik } & Salvinia natans & $163^{\mathrm{a}}$ & $60^{\mathrm{c}}$ & $81^{\mathrm{b}}$ & $44^{\mathrm{d}}$ & $39^{\mathrm{d}}$ \\
\cline { 2 - 7 } & Utricularia vulgaris & $55^{\mathrm{a}}$ & $54^{\mathrm{a}}$ & $45^{\mathrm{d}}$ & $48^{\mathrm{b}}$ & $47^{\mathrm{c}}$ \\
\hline \multirow{2}{*}{ Sinjak } & Salvinia natans & - & $54^{\mathrm{a}}$ & $42^{\mathrm{c}}$ & $43^{\mathrm{b}}$ & $32^{\mathrm{d}}$ \\
\cline { 2 - 7 } & Utricularia vulgaris & $39^{\mathrm{e}}$ & $52^{\mathrm{a}}$ & $47^{\mathrm{b}}$ & $45^{\mathrm{d}}$ & $46^{\mathrm{c}}$ \\
\hline
\end{tabular}

Data on the ability of plants to adopt different types of metal could be very important in the selection of species in phytoremediation technique. In the tissue of Salvinia natans, the highest Mn concentrations were measured in July and August (vegetation peak), whereas in September, a significant decrease in the Mn content was observed. Research by Branković et al. (2009) showed that submerged plants had smaller Mn accumulation capacity compared to floating plants, which is not in accordance with our findings. The value of $\mathrm{Mn}$ was measured in the tissue of Utricularia vulgaris $(620 \mathrm{mg} / \mathrm{kg}$ ) was highest in May in Necik locality, whereas the Mn content in the tissue of $U$. vulgaris varied more during the (May-September) season compared to Salvinia natans.

\section{Accumulation of zinc}

The results presented in Table 4 show that, on an average, the $\mathrm{Zn}$ contents for investigated species was highest at the beginning of vegetation period (May-June) and decreased in autumn, which was in line with the previous results (Maksimović et al., 2014).

Such a seasonal distribution could be a result of antagonism with other elements, Mn and $\mathrm{Fe}$, first of all, but it could also be connected to other environmental factors ( $\mathrm{pH}$, temperature, oxygen contents). Significant differences in $\mathrm{Zn}$ contents (accumulation capacity) were recorded between studied species: the highest accumulation capacity was expressed by floating $S$. natans in comparison with submerged Utricularia vulgaris species. Zn contents during the season (May-September) in Salvinia natans tissue vary from 32 to $163 \mathrm{mg} / \mathrm{kg}$, where measured values were higher compared to the results for Ečka fishpond (Babović et 
al., 2010) and Jegrička River (Borišev et al., 2008). Highest Zn content was measured in S. natans tissue in May $(163 \mathrm{mg} / \mathrm{kg}$ ), whereas $\mathrm{Zn}$ content decreased for $80 \%$ by the end of vegetation period. It is well known that all fertilisers and pesticides contain $\mathrm{Zn}$ (Prasad et al., 2006), so that their increased usage at the beginning of season consequently increases $\mathrm{Zn}$ accumulation in plants. Afterwards, $\mathrm{Zn}$ content in $S$. natans tissue decreases as its deposition in sediments increases. In the tissue of Utricularia vulgaris, 35\% lower contents of $\mathrm{Zn}$ was measured compared to Salvinia natans at Necik locality, and 9\% higher was measured at Sinjak locality (Table 4). The results obtained in this study show that $\mathrm{Zn}$ contents was higher in submerged leaves in comparison to floating leaves, which had been in accordance with the results of Stanković et al. (Stanković et al., 2000). Different studies (Liu et al., 2007; Tyler, Olsson, 2001; Maksimović et al., 2014) show that $\mathrm{Zn}$ adsorption is much better in alkali soil. As the investigated localities belong to the slightly alkali soil, it could be supposed that changes in $\mathrm{Zn}$ contents in our research could be because of mobility of $\mathrm{Zn}$ from sediment during the season (May- September) (Tables 1 and 4). As the investigated localities belong to the slightly alkali soil, it could be supposed that changes in $\mathrm{Zn}$ contents could be connected to mobility of $\mathrm{Zn}$ from sediment during the season (May-September).

\section{Accumulation of copper}

Contents of copper in S. natans tissue were at the detection limits during May, June and October at both the localities and increased contents $(7.94 \mathrm{mg} / \mathrm{kg})$ were detected in August and September (Table 5).

$\mathrm{T}$ a b l e 5. Cu contents $(\mathrm{mg} / \mathrm{kg})$ in tissues of Salvinia natans and Utricularia vulgaris at researched localities. The different letters in each row show a statistically significant difference $(\mathrm{p}<0.05)$ for one heavy metal per month.

\begin{tabular}{|c|c|c|c|c|c|c|}
\hline \multirow{2}{*}{\multicolumn{2}{|c|}{ Plant species }} & \multicolumn{5}{|c|}{ Period (month) } \\
\hline & & \multirow{2}{*}{$\begin{array}{c}\text { May } \\
<0.043\end{array}$} & \multirow{2}{*}{$\begin{array}{c}\text { June } \\
<0.043\end{array}$} & \multirow{2}{*}{$\frac{\text { July }}{3.00^{\mathrm{b}}}$} & \multirow{2}{*}{$\begin{array}{c}\text { August } \\
7.33^{\mathrm{a}} \\
\end{array}$} & \multirow{2}{*}{$\begin{array}{c}\text { September } \\
7.94^{\mathrm{a}}\end{array}$} \\
\hline Necil & Salvinia natans & & & & & \\
\hline Necik & Utricularia vulgaris & $8.00^{\mathrm{a}}$ & $6.03^{c}$ & $4.75^{\mathrm{e}}$ & $5.87^{\mathrm{d}}$ & $6.56^{\mathrm{b}}$ \\
\hline \multirow{2}{*}{ Sinjak } & Salvinia natans & - & $<0.043$ & $6.30^{\mathrm{a}}$ & $6.25^{\mathrm{a}}$ & $1.87^{\mathrm{b}}$ \\
\hline & Utricularia vulgaris & $10.18^{\mathrm{a}}$ & $1.70^{\mathrm{d}}$ & $3.87^{\mathrm{c}}$ & $4.37^{b}$ & $4.37^{\mathrm{b}}$ \\
\hline
\end{tabular}

As a consequence of $\mathrm{Cu}$ antagonism with $\mathrm{Fe}$, on the one hand, absorption of $\mathrm{Cu}$ from sediment is decreased, and, on the other hand, $\mathrm{Cu}$ toxic concentrations can be mitigated by adding Fe (Prasad, 2003; Rai, 2009). Owing to it antagonistic relations with Fe and as a consequence of increased Fe concentration at researched localities, both availability and intake of $\mathrm{Cu}$ by aquatic plants drastically decreased. Cu contents in the tissue of Utricularia vulgaris varied from 1.7 to $10.18 \mathrm{mg} / \mathrm{kg}$, whereas higher contents were measured at Necik locality compared to Sinjak locality. Other authors also showed that $\mathrm{Cu}$ accumulated better in tissue of submerged plants compared to floating and emerged plants (Stanković et al., 2000; Pajević et al., 2002; Babović et al., 2010). 


\section{Accumulation of lead}

Lead contents in the tissue of Salvinia natans and Utricularia vulgaris during the research period was under the detection limit $(<0.51 \mathrm{mg} / \mathrm{kg})$, which was significantly lower compared to the previous researches (Branković et al., 2009; Khellaf, 2009; Štrbac et al., 2014). In all plant species, contents of $\mathrm{Fe}, \mathrm{Mn}, \mathrm{Cu}$ and $\mathrm{Zn}$ were higher at Necik locality compared to Sinjak locality, which are most probably consequence of different physical-chemical environmental conditions, better availability of researched element and the presence of metals in soluble form, that is, its faster release from sediment.

Depending on the species, the seasonal cycle of aquatic macrophytes can mainly be characterised by faster growth in spring, maximum of growth at the end of the summer and more or less rapid growth decline in autumn, so macrophytes are thought to affect seasonal storage and circulation of elements in the aquatic environment (Prasad et al., 2006). The degree of accumulation of heavy metals depends on the plant species, locality and the sampling period. From the results obtained shown in the Tables 2-5, it can be seen that accumulation of Mn in $U$. vulgaris was increased during the period of flowering, whereas the content of $\mathrm{Fe}, \mathrm{Zn}$ and $\mathrm{Cu}$ was lower compared to the beginning of the season (May-September). In Salvinia natans, the higher content of $\mathrm{Fe}$ and $\mathrm{Zn}$ was recorded at the beginning of the season (May-September) and $\mathrm{Mn}$ was recorded during the period from July to August, whereas $\mathrm{Cu}$ content increased more with the plant aging.

\section{Phytoremediation potential of Salvinia natans and Utricularia vulgaris}

The level of bioaccumulation is the result of the difference between the amount of metals that the plant adopts and its amounts in water and sediment and is specific to each plant species (Ghosh, Singh, 2005; Prasad et al., 2006). Also, the bioaccumulation coefficient depends on many factors of the environment in which the plant is located $(\mathrm{pH}$, temperature and oxygen concentration).

The BAC is used as an indication of the potential of heavy metal accumulation for those plant species that have a well-developed cellular mechanism for detoxification and tolerance of heavy metals (Ghosh, Singh, 2005; Maksimović et al., 2008). The BAC values varied in relation to the type, metal, and sampling period (Table 6).

The BAC values for Fe in Salvinia natans leaves ranged from 1.40 to 2.29, 1.89-2.30 for $\mathrm{Mn}$; 0.73-1.15 for $\mathrm{Zn}$ and 1.21-1.23 for $\mathrm{Cu}$. The BAC values obtained for Fe and $\mathrm{Zn}$ in Utricularia vulgaris were twice lower, whereas $\mathrm{Mn}$ was higher in relation to Salvinia natans. For $\mathrm{Cu}, \mathrm{BAC}$ values similar in both the species. The average BAC values were higher at the Necik locality compared to Sinjak for all heavy metals. Therefore, the investigated species have mostly BAC $>1$ or, for $\mathrm{Zn}, \mathrm{BAC} \sim 1$, indicating that $S$. natans and Utricularia vulgaris have pronounced accumulation properties and can be successfully applied in phytoremediation techniques. It is very important to note that the results obtained depend not only on the total concentration of metals in the sediment but also on the physical and chemical characteristics of water, in particular the $\mathrm{pH}$, as well as the ability to change the ions between the sediment of water and plant species (Yoon et al., 2006). 
$\mathrm{T} \mathrm{a} \mathrm{b} \mathrm{l} \mathrm{e} \mathrm{6.} \mathrm{Average} \mathrm{values} \mathrm{of} \mathrm{the} \mathrm{BAC} \mathrm{coefficient} \mathrm{in} \mathrm{relation} \mathrm{to} \mathrm{the} \mathrm{content} \mathrm{of} \mathrm{heavy} \mathrm{metals} \mathrm{in} \mathrm{sediment} \mathrm{for} \mathrm{Fe}, \mathrm{Mn}$, $\mathrm{Zn}$ and $\mathrm{Cu}$ at the investigated localities in the area of Bardača fishponds during the period from May to September.

\begin{tabular}{|l|c|c|c|c|}
\hline & Fe & Mn & Zn \\
\hline Locality & \multicolumn{4}{|c|}{ Salvinia natans } \\
\hline Necik & 2.29 & 1.90 & 1.14 & 0.66 \\
\hline Sinjak & 1.61 & 1.26 & 0.60 & 1.22 \\
\hline & \multicolumn{4}{|c|}{ Utricularia vulgaris } \\
\hline Necik & 1.40 & 2.30 & 0.73 & 0.79 \\
\hline Sinjak & 1.32 & 1.60 & 0.79 & 0.84 \\
\hline
\end{tabular}

$\mathrm{T}$ a b l e 7. Average values of the BCF coefficient in relation to the content of heavy metals in water for Fe, Mn, $\mathrm{Zn}$ and $\mathrm{Cu}$ at the investigated localities in the area of Bardača fishponds during the period from May to September.

\begin{tabular}{|l|c|c|c|c|}
\hline & Fe & Mn & $\mathrm{Zn}$ \\
\hline Locality & \multicolumn{4}{|c|}{ Salvinia natans } \\
\hline Necik & 16.902 & 7.918 & 2.901 & 215 \\
\hline Sinjak & 5.769 & 3.358 & 1.515 & 271 \\
\hline & \multicolumn{4}{|c|}{ Utricularia vulgaris } \\
\hline Necik & 8.494 & 9.686 & 1.884 & 223 \\
\hline Sinjak & 4.854 & 4.939 & 1.579 & 276 \\
\hline
\end{tabular}

The plant accumulates heavy metals independently of their concentration in water and sediment, which is obvious from the results obtained (Fig. 2, Table 1). Differences between plants in bioaccumulation can be a consequence in the translocation of heavy metals through the plant because the bioaccumulation capacity of plants' tissue for certain metals is different. According to Zayed et al. (1998), plant is considered as good bioaccumulator if the BCF exceeds 1.000. BCF in relation to the water in the leaves of Salvinia natans and Utricularia vulgaris, shown in Table 7, indicates that the accumulation of heavy metals decreases in the following order: $\mathrm{Fe}>\mathrm{Mn}>\mathrm{Zn}>\mathrm{Cu}$ at both the localities. Salvinia natans have a higher BCF for Fe and $\mathrm{Zn}$, whereas Utricularia vulgaris showed a higher bioaccumulation capacity to $\mathrm{Mn}$ and $\mathrm{Cu}$.

\section{Conclusion}

On the basis of the measured heavy metals concentrations ( $\mathrm{Fe}, \mathrm{Mn}, \mathrm{Cu}, \mathrm{Zn}$ and $\mathrm{Pb}$ ) in sediment, we can conclude that investigated localities are not overloaded by these pollutants, which are dangerous for ecosystem. Taking into account all the results obtained, we can conclude that $U$. vulgaris and Salvinia natans accumulate $\mathrm{Fe}, \mathrm{Mn}$ and $\mathrm{Zn}$ in a high degree. Both species proved to be insufficient bioindicators for $\mathrm{Cu}$ and $\mathrm{Pb}$. The results acquired in this study at the area of Bardača fishpond imply that bioaccumulation of heavy metals and their availability to the plants had not reached critical level. Hence, it is important to set a constant 
monitoring to include monitoring of seasonal and spatial variations in the accumulation of heavy metals with the aim of estimating the capacity of researched species in phytoremediation techniques.

\section{Acknowledgements}

This work was partially funded by the Foundation 'Dr Milan Jelic' within the Ministry of Science and Technology of the Republic of Srpska (grant number 01-2-473-1/10).

\section{References}

American Public Health Association (APHA) (1995). Standard methods for the examinations of water and wasterwater. New York: American Public Health Association Inc.

Babović, N., Drazić, G., Djordjević, A. \& Mihailović N. (2010). Heavy and toxic metal accumulation in six macrophythe species from fish pond Ecka, Republic of Serbita. BALWOIS - Ohrid, Republic of Macedonia, (25-29 May 2010) (pp. 1-6). Republic of Serbita.

Borišev, M., Pajević, S., Stanković, Ž. \& Krstić B. (2008). Macrophytes as indicators and potential remediators in aquatic ecosystems: a case study. Large Rivers, 18 (1-2), 107-115. DOI: 10.1127/1r/18/2008/107.

Branković, S., Pavlović-Muratspahić, D., Topizović, M. \& Milojević J. (2009). Concentration of Metals (Fe, Mn, Cu and $\mathrm{Pb}$ ) in come aquatic macrophytes of lakes Gruža, Grošnica, memorial Park-Kragujevac and Bubanj. Kragujevac Journal of Science, 31, 91-101.

Canadian Council of Ministers of the Environment (1999). Canadian sediment quality guidelines for the protection of aquatic life: Introduction. In Canadian Environmental Quality Guidelines (pp. 1-5). Winnipeg: Canadian Council of Ministers of the Environment.

Dhir, B. \& Srivastava S. (2013). Heavy metal tolerance in metal hyperaccumulator plant, Salvinia natans. Bull. Environ. Contam. Toxicol., 90(6), 720-724. DOI: 10.1007/s00128-013-0988-5.

Ghosh, M. \& Singh S.P. (2005). A review of phytoremediation of heavy metals and utilization of it's by- products. Applied Ecology and Environmental Research, 3(1), 1-18. http://www.ecology.kee.hu

Grisey, E., Laffray, H., Contoz, O., Cavalli, E., Mudry, J. \& Aleya L. (2012). The bioaccumulation performance of reeds and cattails in a constructed treatment wetland for removal of heavy metals in landfill leachate treatment (Etueffont, France). Water Air Soil Pollut., 223, 1723-1741. DOI: 10.1007/s11270-011-0978-3.

Grudnik, Z.M. (2010). Seasonal changes in the concentration of some trace elements in macrophyte shoots. Acta Biol. Slov., 53(1), 55-61.

Khellaf, N. \& Zerdaoni M. (2009). Phytoaccumulation of zinc by the aquatic plant, Lemna giba L. Bioresour. Technol., 100, 6137-6140. DOI: 10.1016/j.biortech.2009.06.043.

Li, M.S., Luo, Y.P. \& Su Z.Y. (2007). Heavy metals concentrations in soils and plant accumulation in a restored manganese mine land in Guangxi, South China. Environ. Pollut., 147, 168-175. DOI: 10.1016/j.envpol.2006.08.006.

Liu, J., Dong, Y., Xu, H., Wang, D. \& Xu J. (2007). Accumulation of Cd, Pb and Zn by 19 wetland plant species in constructed wetland. J. Hazard. Mater., 147(3), 947-953. DOI: 10.1016/j.jhazmat.2007.01.125.

Maksimović, T., Stanković, Ž.\& Ilić P. (2007). Bioakumulacija Mn, Cd, Pb u vodenim makrofitama na području ribnjaka Bardača. In 36. Konferencija o aktuelnim problemima korišćenja i zaštite voda, "Voda 2007” (pp. 131-136). Tara: Jugoslovensko društvo za zaštitu voda.

Maksimović, T. \& Ilić P. (2008). Bioakumulacija teških metala kao pokazatelj potencijala bioremedijacije vodenih biljaka na području ribnjaka Bardača. In 37. Konferencija o aktuelnim problemima korišćenja $i$ zaštite voda, "Voda 2008" (pp. 131-136). Tara: Jugoslovensko društvo za zaštitu voda.

Maksimović, T., Borišev, M. \& Stanković Ž. (2014). Seasonal dynamics of copper and zinc accumulation in shoots of Phragmites australis (CAV.) Trin. Ex Steud., Typha latifolia L. and Typha angustifolia L. Matica Srpska Journal for Natural Sciences, 127, 65-75. DOI: 10.2298/ZMSPN1427065M.

Maksimović, T., Rončević, S. \& Kukavica B. (2016). Bioaccumulation of iron and manganese in some water macrophytes in the area of Bardača pond. Skup, 7(2), 87-96.

Map of Bardača fishpond (a detail from topographic map 1:25000, Nova Gradiška (Razboj-Ljevčanski) 4-4, Vojnogeografski institut, 1977 (Military Geographic Institute). 
Nouri, M. \& Haddioui A.E.M. (2016). Assessment of metals contamination and ecological risk in ait ammar abandoned iron mine soil, Morocco. Ekológia (Bratislava), 35(1), 32-49. DOI: 10.1515/eko-2016-0003.

Pajević, S., Vučković, M., Stanković, Ž., Kevrešan, Ž. \& Radulović S. (2002). The contents of some macronutrients and heavy metals in aquatic macrophytes of three ecosystems connected to the Danube in Yugoslavia. Large Rivers, 13(1-2), 73-83. DOI: 10.1127/lr/13/2002/73.

Pant, P.P. \& Tripathi A.K. (2014). Impact of heavy metals on morphological and biochemical parameters of Shorea robusta plant. Ekológia (Bratislava), 33(2), 116-126. DOI: 10.2478/eko-2014-0012.

Prasad, M.N.V. (2003). Phytoremediation of metal polluted ecosystems: hype for commercialization. Russian Journal of Plant Physiology, 50(5), 686-701. DOI: 10.1023/A:1025604627496.

Prasad, M.N.V., Greger, M. \& Aravind P. (2006). Biogeochemmical cycling of trace elements by aquatic and wetland plants: Relevance to phytoremediation. In M.N.V. Prasad, K.S. Sajvan \& R. Naidu (Eds.), Trace elements in the environment, biogeochemistry, biotechnology, and bioremediation (pp. 443-474). Florida: CRC Press, Now Taylor and Francis.

Prica, Lj., Dalmacija, B., Ivančev-Tumbas, I., Krčmar, D., Rončević, S., Bečelić, M. \& Jovanović D. (2005). Metali u pojedinim zaštićenim zonama u Vojvodini. In 34. Konferencija o aktuelnim problemima korišćenja i zaštite voda, "Voda 2005" (pp. 93-99). Kopaonik: Jugoslovensko društvo za zaštitu voda.

Rahmani, G.N.H. \& Sternberg S.P.K. (1999). Bioremoval of lead from water using Lemna minor. Bioresour. Technol., 70, 225-230. DOI: 10.1016/S0960-8524(99)00050-4.

Rai, P.K. (2009). Heavy metal phytoremediation from aquatic ecosystems with special reference to macrophytes. Crit. Rev. Environ. Sci. Technol., 39(9), 697-753. DOI: 10.1080/10643380801910058.

Raičević, V., Božić, M., Rudić, Z., Lalević, B. \& Kiković D. (2011). The evolution of the eutrophication of the Palić Lake (Serbia). African Journal of Biotechnology, 10(10), 1736-1744. DOI: 10.5897/AJBx10.028.

Stanković, Ž., Pajević, S., Vučković, M. \& Stojanović S. (2000). Concentrations of trace metals in dominant aquatic plants of the Lake Provala (Vojvodina, Yugoslavia). Biol. Plant., 43(4), 583-585. DOI: 10.1023/A:1002806822988.

Šarić, Ž., Maksimović, Č., Stanković, M. \& Butler D. (2004). Life in wetland (pp. 17-27, 59-67). Banja Luka: The Institute For Urbanism of Republic Srpska.

Štrbac, S., Šajnović, A., Grubin, K., Vasić, M., Dojčinović, N., Simonović, B. \& Jovančićević B. (2014). Metals in sediment and Phragmites australis (Common Reed) from Tisza River, Serbia. Applied Ecology and Environmental Research, 12(1), 105-122. http://www.aloki.hu

Tyler, G. \& Olsson T. (2001). Concentrations of 60 elements in the soil solution as related to the acidity. Eur. J. Soil Sci., 52(1), 151-165. DOI: 10.1046/j.1365-2389.2001.t01-1-00360.x.

Vrom (2000). Circular on target values and intervention values for soil remediation. DBO/1999226863. Ministry of Housing, Spatial Planning and Environment Directorate-General for Environmental Protection, Department of Soil Protection. The Hague. Published in the Netherlands Government Gazette No. 39 on 4 February 2000.

Yoon, J., Cao, X., Zhou, Q. \& Ma L.Q. (2006). Accumulation of Pb, Cu, and $\mathrm{Zn}$ in native plants growing on a contaminated Florida site. Sci. Total Environ., 368(2-3), 456-464. DOI: 10.1016/j.scitotenv.2006.01.016.

Yurkova, L. \& Kochev H. (1996). Heavy metal concentrations in main macrophytes from the Srebarna Lake along the Danube (Bulgaria). 31. Konferenz der IAD, Baja-Ungarn, Wissenschaftliche Referate. Limnologishe Berichte Donau, Band I, 195-200).

Zakon o vodama (2001). Službeni glasnik Republike Srpske (br. 10/98; 3/97; $3 / 8$ i 29/00), Uredba o klasifikaciji voda i kategorizaciji vodotoka, 2001.

Zayed, A., Gowthaman, S. \& Terry N. (1998). Phytoaccumulation of trace elements by wetland plants: I. Duckweed. J. Environ. Qual., 27, 715-721. 